\title{
Questions and positions on education for sustainable development at university in France: Example of short professional cycles
}

A. BARTHES, Y. ALPE, B. BADER (2012), Questions and positions on education for sustainable development at university in France: example of short professional cycles? Environmental Education Research, Volume 0, Issue 0, pages 1-13

(http://www.tandfonline.com/doi/full/10.1080/13504622.2012.690854)

Summary: The questions focus on the emergence of education for sustainable development in the French university. The case study discusses the curricular examination of the Bachelor of Territory Professional Planning in 17 universities and the diachronic evolution, between 2001 and 2011, of their educational content around sustainable development. The analysis leads to a reflection on the specificity of French contexts, compared to international positions. Indeed, the legitimacy of the education provided is queried against the economization of the educational sphere. Didactic problems are posed by the reduction of distances between social practices and knowledge mobilized for the teachings. The evolution of the "school form" and the specific place of "educations for" in the framework of the institution are questioned.

Keywords: French contexts, Education for Sustainable Development, school form, university pedagogy, legitimacy

Introduction: In France, the "school form" established in the late nineteenth century (Vincent, 1994, Monjo, 1998) led to, admittedly, as necessities inherent in the act of teaching, a certain number of features: impersonal rules and hierarchical structure in the classroom, one teacher in charge of a group of students sorted by age, the existence of a distinct and closed location. But the school form also applies to educational content, by imposing a horizontal division of knowledge into "school subjects", based on scientific knowledge for reference. It assumes a cumulative nature of knowledge, and a control of the transmission process and its results (examinations, diplomas, inspections). These characteristics of the school form were also described and discussed in schools and universities in the United States and Canada. Henry Giroux and the authors of critical pedagogy offer a thorough analysis of this subject (Giroux, 1988, 2006).

In France, its organization builds, from the time of J. Ferry, on the definition of specific issues that go far beyond the framework of the school: eradication of local particularities, the spreading of values of modernity, the exaltation of national pride and citizenship. It is recognized that education as a whole contributes to it, as it contributes to the symbolic figurehead of the schoolmaster. The education system is thus designed both to teach and educate. These sociopolitical functions of the school (Prost, 1992), analyzed since the beginning of the twentieth century by E. Durkheim (1992) thus justify the presence in the teachings of values (ethics, citizenship, patriotism ...) or even ideological positions that were rarely questioned until the sixties.

This positioning of values experienced a progressive narrowing in the slow process of the didactization of school content (1960-1990). The massification of education (Merle, 2009) gives 
priority to the content of knowledge. Mistrust resulting from the questioning of ideologies (Baudelot \& Establet, 1972) of the functions of the school (inequality of educational opportunities, the role of cultural capital ...) through the development of the sociology of education and the "theory of reproduction "(Bourdieu \& Passeron, 1970) led to the suspicion of anything that seemed to be more or less of a" hidden curriculum " (Perrenoud, 1993). Thus, many professors consider themselves strictly as teachers; they are no longer educators. They base their social legitimacy on the scientific and academic legitimacy of the knowledge they provide. Education in school will therefore organize itself around the question of the fundamental knowledge to teach. It consists of determining a minimal educational base required, which is divided by categories of age.

In parallel, a utilitarian concept of education is drawn based on future employability, which is accompanied by the rise of the competency model inspired by the enterprise (Rope \& Tanguy, 1994). It claims to meet a crisis in education (Joshua, 1999), characterized by the doubt about the social utility of knowledge. Thus, in Quebec, there is a reaffirmation of the importance of teaching the fundamental knowledge in school before the implementation of referentials for progression of learning in primary schools and secondary schools, in addition to focusing on skills development in schools ( «See for example : Ministry of Education, Recreation and Sports, Government of Quebec, 2008).

The rise, at least in the perceptions of social problems such as environmental degradation, incivility and violence, will bring a new change with the emergence in the 90's in France of Environmental Education (Girault \& Sauvé, 2008), followed by Civic, Legal and Social Education (Alpe \& Legardez, 2000), Health Education (Eymard, 2004) and Education for Sustainable Development (ESD). These "educations for" (Audigier \& Tutiaux-Guillon, 2008) call into question the sharing between the function of instruction, centered on knowledge, and the function of education, centered on the values to be transmitted. These same issues arise in the North American context, Canadian and Quebecker, as to the nature of values to be transmitted or preferred style of teaching, especially when it comes to education related to the environment and sustainable development (Bader, 2008, 2005; Sauvé and Orellana, 2008; Sauvé 2007).

This article is placed in this context and its purpose is to show, from the example of ESD at the university, how in France, there is a rupture in the educational logics, which raises questions about the legitimacy of content transmitted. Our work is also situated in a broader international perspective, in line with those who question ESD in university programs, whether in Europe (Sterling and Scott, 2008, Ségalas, Ferrer-Balas, Svanstrom, Lundvist \& Mulder, 2009), in a North American context or elsewhere (Ferrer-Balas, Adachi, Banas, Davidson, Hoshikoshi, Mishra, Motodoa, Onga \& Ostwald, 2008).

\section{Content and practices of ESD at the university in France}

\section{From supranational political order to the French adaptation}

In education systems today, the organization of ESD is a response to the UN program of sustainable development (Sauvé, 2006). UNESCO, acting as an implementing agency of the United Nations, has set up a "decade of ESD" (2004-2014), whose objective is to stimulate 
reforms of education systems and curricula to promote sustainable development. Relayed by the European bodies, and then states, the demands on universities have gradually increased. Higher education institutions must lead the way, through ESD, towards the implementation of sustainable development. Thus, as critically observed by Lucie Sauvé, "Sustainable development is the subject of an educational project prescribed by the authorities of both international and national governance, and the education community must engage" (Sauvé, Berryman \& Brunelle, 2003).

This stance therefore calls ESD in a resolutely political direction (Jicking and Wals, 2008), starting from international bodies and spreading in universities. Laval and Weber (2002) even speak of a "new order global education."

In this sense, the Talloires Declaration ${ }^{1}$ is the first official mark of commitment from universities towards promoting education for sustainable development. Signed by 350 universities, it is intended, among other things, to "develop a mindset in institutions focused on sustainable development", and focus on "education leading to an environmentally responsible citizenship". Implementations are reinforced by international conferences, which give more importance to the commitment of universities to education for sustainable development.

In France, the Grenelle of the environment specifies the modalities for the dissemination of education for sustainable development by requiring all higher education institutions to prepare, for the start of 2009, a "Green Plan" for the campus. This same type of project can be found in the English universities (Beringer, Adomßent and Scott, 2008). The objectives are numerous: integrating sustainable development in training, making ESD fully interdisciplinary, providing teachers with pedagogical tools and specific training, integrating sustainable development in study missions, advice or support from businesses or communities that can lead the institution or its students; integrating sustainable development into courses and / or business projects, supporting and enhancing student engagement in the achievement of sustainable development projects.

In this context, university education experiences rapid evolution, and ESD is supposed to be gradually more pertinent. These developments need to be clearly formulated and analyzed with respect to their objective and consequences. Indeed, the hypothesis is made here, that in the absence of a formal curriculum, courses tend to be organized around values and practices to the detriment of the disciplinary scientific content.

\section{Content oriented by the practices of actors and the partnership}

Indeed, as everywhere, ESD as environmental education puts forward a principle of partnership or collaboration with local associations and the associated sphere (Villemagne, 2006; Corcoran \& Osano, 2009). This partnership stipulates the idea of educational co-construction in the sense of collaboration between the different actors involved in the process of developing guidelines and training content. This position raises a number of criticisms as much as from a point of view on ethical issues related to the educational institution (Brussels, 2006), as from the point of view of

\footnotetext{
1 This declaration can be consulted on the internet : http://www.ulsf.org/pdf/French_TD.pdf
} 
the legitimacy of the teachings. The authors even formulate the idea of a utilitarian and dominant partnership (Barthes \& Champollion, 2011).

In fact, the frameworks of territorial actions, project-based teaching, and the autonomy of universities insert the universities in a multi-stakeholder dynamic. Indeed, the implementation of sustainable development comes in the form of local agendas, with communities engaging in them through various approaches and generating, through their role as financiers, partnerships between universities and local actors. These partnerships are often associative.

The educational activity is therefore formalized in part around these projects. The local translation of public policies of sustainable development will be based on associations that respond to local tenders. The studies to be performed will be helped by the student body and legitimized by the presumed expertise of faculty members and their institutional presence in the project. In return, the association which possesses the application experience of sustainable development approaches inserts the students in a concrete project of sustainable development, valued as a social integration of the university.

Given the context, associative competencies and projects from local territories engage local ESD in two very specific dominant forms in France. The first and most common, is moving towards eco-responsibility, or "good gestures" (sorting of waste, energy conservation, carpooling ...). It justifies its educational position from a point of view of citizen learning. The second form is the formalized project area, which responds to a directly utilitarian vision of sustainable development. It involves technical training such as spatial planning, tourism, management, community development, agriculture in ESD ... The fact of systematically relying on partner actors opens the way for justification of content by practices, and not by their scientific legitimacy, as shown by the analysis of curriculum evolutions of university degrees. In this sense, professional licenses for land planning constitute a telling example.

\section{Case Study}

The study presented here as an illustration concerns the curriculum evolution of degrees in the field of territory planning between 2001 and 2011. With the introduction of ESD at the university, a change is occurring in the display of degrees towards sustainable development over the last two four-year contracts. The issue is whether this is just a display, or if there is a real deeper curriculum change, which would transform the real curriculum.

The method of analysis follows a specific protocol, which includes the choice of degrees, the collection and diachronic comparison of course schedules, followed by a detailed analysis of specific teaching modules with the title "sustainable development".

The study focuses on French professional licenses ${ }^{2}$ now labeled "sustainable planning of territories." Previously, the vast majority had a strong environmental display. 17 degrees were thus selected (All in France concerning Land Planning in University Institutes of Technology;

2 By professional license, we mean an undergraduate university program that is completed in three years and leads to a professional practice. Most of these licenses are done in the Instituts Universitaires Technologiques (University Institutes of Technology). The analysis will be of the third year. 
see appendix). From these 17 degrees, a list of titles of the courses was established in 2001 and 2011. The various elements of the list of titles of the courses were grouped into categories. For example, "Basic statistics", "Elements of statistics," and "Data processing and statistics" were grouped in the category "statistics". But other groups were less straightforward. For example, should "sustainable development of rural areas" be classified as sustainable development or rural geography? In 8 cases, it was not possible to group the courses spontaneously. A telephone interview with the head of the degree or the module in question was conducted to clarify the real curriculum. This sometimes forced the sequencing of the content of courses in order to specify the distribution by categories.

After the regrouping of teachings by categories for 2001 and 2011, the volumes of class schedules that were actually given were associated to them. A diachronic type of a statistical treatment was then performed. Changes in the volume of schedules between the two dates, either positive or negative and greater than 7 hours were extracted and analyzed. To clarify these results, a closer analysis of the contents of the courses entitled "sustainable development" was conducted by telephone interview, and completed at the University of Provence with a questionnaire to stakeholders.

The results make it possible to identify the major curriculum changes that occurred between 2001 and 2011.They concern five main aspects:

1 - The introduction of a non-prescribed curriculum of ESD modules (+ 22 hours between 2001 and 2011, as an average)

The curricular precisions based on interviews and complementary surveys show that these courses are geared toward the know-how and behaviors to be implemented. They are the result of a multitude of stakeholders that present numerous applications for land planning. The capitalization of experiences that could be considered as renewable helps guide the following experiments. The course is often organized as a series of conferences. It also brings together stakeholders from various statuses such as teachers, lecturers, and professionals, and echoes the partnership trend of ESD at the University. The content of the course is normally the result of a tacit agreement among stakeholders, including a large thematic dispersion without reference to programs, and often without an effort of articulation. A questionnaire submitted in 2009 to 35 stakeholders in sustainable development modules (15 responses received) performed at the University of Provence actually shows that the spread of topics covered is important: the issue of "actors" comes out on top (6 occurrences), followed by "energy" (5) and "economy" (4); the theme of "environment" is absent. Also as part of the survey, in $80 \%$ of responses, the ESD does not refer to scientific fields, which confirms the order of importance of the choices in terms of the purpose of teaching. The most important are "Training of citizens" (14 occurrences), "Sharing of values" (13); "Explaining scientific phenomena" appears only in the fifth position (9). The orientation of the sustainable development course is constant in all degrees: you must inform to change individual behavior and the purpose of the module is a militant goal - the stakeholders being themselves all involved in movements for sustainable development. We are in education (liked to values), not in teaching (liked to knowledge), even if the school form is largely respected (conferences listed in the schedule, questionnaire at the end of module). But in feedback from stakeholders, it is perceived as an obstacle to the educational mission. 
2 - There is the proliferation of specialized courses on sustainable development. They correspond to the acquisition of "good actions" taken in their professionalizing dimension. These include, for example, courses in "the development of sustainable tourism sectors," or "organization of alternative mobility services "(+8 hours between 2001 and 2011). The lessons of this type are usually the result of a single stakeholder, who develops advanced technical aspects in a particular field of sustainable development. They are in the field of engineering.

3 - The implementation of the principles of governance requires a strong adaptation to new skills related to managerial ability. This is also reflected in the emergence of methodological lessons, which pertain to project management and to all the phases of its implementation $(+21$ hours, as an average), as well as the diagnosis of the territory (+ 20 hours), or "communication skills" $(+20$ hours). They refer to the acquisition of new skills required by new jobs, such as "sustainable development trainers", "project leaders", "ESD project managers"....

4 - These changes are accompanied by an increase in the number of hours in law ( +8 hours), which reflects the genesis of a new organizational and regulatory framework related to sustainable development.

5 - With the volume of lessons remaining broadly stable, new lessons are installed at the expense of others. Paradoxically, these are matters related to ecology and environmental science that lose importance, and to a lesser extent to the more general lessons. Indeed, when environmental protection was valued, knowledge of the environment constituted much of the knowledge to acquire strongly linked to well-identified scientific disciplines: biology, life sciences, geology, climatology, ecology, physical geography. These lessons are reduced on average by 50 hours per training between 2001 and 2011. In the same spirit, the lessons concerning the knowledge of societies, such as geography or sociology, decrease (-25 hours). The general lessons (English, applied mathematics) are also reduced by an average of 15 hours.

All these changes show that school subjects and academic knowledge give way both to nondisciplinary content that is supposed to concern ESD in the broad sense, as well as to to transversal know-how. The changes also show than an emphasis is made on partnerships and political principles of organizational changes in governance. These changes call for a broader reflection on the educational logic and the educational issues surrounding their modifications.

\section{The legitimacy of ESD, between knowledge and practices in an academic context}

\section{Questions about the legitimacy of ESD}

ESD does not have the usual characteristics of disciplines; it is situated outside of the traditional form of teaching, as shown for example by the scientific paper presenting the research program ANR ED2AO : ESD, supports and barriers, 2008 - 2012 (Lange, 2008). It provides the specificity of a form of education in France that is explicitly qualified as "education for": 
"ESD is part of all "educations for" which it combines most of the features [...] an interconnection of issues as much from the educational point of view (centering on the life experiences, skills, mixed nature, controversies, knowledge involved) as from the societal perspective (overlapping of environmental, health, social and economic issues); similarity of instructional approaches to promote their educational aspect and not their subjection to utilitarian objectives; the decisive and involved position of the subject in its social dimension, its values and its knowledge-representation systems, as much for the student as for the teacher. "

The "educations for" in France therefore have a special status, and a review of commonalities reveals four main features. They are thematic (the environment, health ...) and non-disciplinary, which distinguishes them from the standard model of academic content of a scientific nature. They have a close relationship with lively social issues (Legardez \& Simonneaux, 2006) because they focus on problems that arise in society, and are a response to a form of social demand for education. They can be controversial. They place a high value on values: "ESD must form a scientific approach and foresight, enabling every citizen to make choices and commitments by supporting them with a lucid and informed reflection. It should also lead to a reflection on values, awareness of individual and collective responsibilities and the need for solidarity between intraand intergenerational territories "(Circular 2007-077, Ministry of National Education).

Moreover, in France, ESD conforms fairly well to the requirements of UNESCO. This organisation publishes a "compendium of good practices - ESD" ${ }^{3}$ ", which states (p. 7): "Education is an essential tool in changing values and attitudes, behaviors and lifestyles, making them consistent with sustainable development." Some researchers are particularly critical of this requirement, thinking that ESD is only a utilitarian approach with economic goals (Sauvé 2006, Jickling 1992, Alpe 2006, Barthes and Champollion, 2011).

As a result, the scientific legitimacy of reference knowledge in ESD is not obvious. The contents borrow from many fields of science without a conceptual matrix, and to use the vocabulary of the sociology of science (Vinck, 1997), without a paradigmatic formation of the field, the latter being the subject of confrontation between experts to define the dominant orientation. They refer in addition to numerous serious social issues (Gayford 2002, Oulton, Dillon, Grace, 2004; Simonneaux, 2009), as shown by the debates on climate change or GMOs.

With ESD being thematic, it is not a school subject and it has no formal curriculum. Therefore, there is no procedure for recognition of competencies to teach: is an"ESD teacher" means one who volunteers to become one, as there is no a priori validation. There are no programs or assessments of knowledge acquired and the national educational institution gives free rein to the development of local curricula. Therefore, there is no prescribed curriculum, which can serve as a basis for the construction of the legitimacy of content, from the perspective of an epistemology of school knowledge (Develay, 1998).

Ultimately, the legitimacy of ESD relies on four elements. On the activist position of the stakeholder: as there is no proof of competence, the stakeholder and the content of the intervention are legitimized «by conviction". This explains the multiplicity of stakeholders associations. It works on the possibility of modifying observable behavior and adequate

\footnotetext{
${ }^{3}$ http://unesdoc.unesco.org/images/0018/001812/181270f.pdf
} 
assumptions. The content is therefore legitimized "by doing", but without social consensus on those practices that are the subject of many questions about their foundations ... It is organized by proximity to some of the lessons that are properly listed in the officially recognized disciplines: biology, geology and so on. The content is thus legitimized by "contagion," or external reference. Finally, the legitimacy of ESD is based on the supposed existence of a global system of reference, of a political-institutional and media-related nature, which would serve as conceptual matrix. The content is thus legitimized by the institutions which are themselves only partly legitimate.

\section{The issue of distance from social practices}

The denial of the distance (generally recognized as necessary in France in the teachings) between social practices and knowledge to teach is a common posture in ESD in France, as shown by courses based on examples of practices of stakeholders or steps towards eco-efficiency: how to organize the sorting of waste, carpooling, water conservation, etc ... Without taking a critical distance and by stressing the technical aspect, to the extent that the distancing of social situations is not done, teaching becomes here a technique of operationalization of procedures. Thus, it is no longer considered necessary to be able to formulate problems surrounding sustainable development in a methodological manner, despite being central to the formation of autonomous citizens. The step is then quickly taken on the risk of normative deviation. "Learning becomes an ethics course focusing on "political correctness" but is not liked any more to scientific knowledge" (Legardez, 2006).

Finally, the negation of the distance between knowledge and social practices crystallises debates about what is a project to set standards of conduct expected to be collectively accepted. Indeed, sustainable development adopts the image of collective responsibility. And all that refers to it appears as indisputably necessary to avoid the destruction of global equilibrium. This normative position induces a relativistic deviation from teachers that is a distortion of knowledge about socially valued attitudes without substantive analysis.

These characteristics mean that ESD is thus positioned high on the scale of the risk of subject content to teach, because of the characteristics of the domain that are concerned: heterogeneity of scholarly reference fields, many scientific controversies, proximity to lively social issues, risk of activation of conflicting values, proximity to social practices.

\section{Discussion of results and the international perspective}

The international perspective shows differences and similarities that should be emphasized, comparing similar types of data.

In all cultural contexts, there is a tension between subject content to teach and intentions for training with respect to practical considerations. However, in an anglophone context, the focus is more readily on projects and case studies as levers to engage students in analyzing and learning about real, complex problems (Steiner and Posch, 2006). However in the French context, the project is more readily seen as a utilitarian approach with economic goals and thus the knowledge to acquire becomes determined by the market. 
Interdisciplinarity is also seen in the Anglo-Saxon context as a dimension that allows students to analyze the environmental, social, economic, cultural and even ethical dimensions of these issues. Thus, the question of the integration of multidisciplinary and interdisciplinary analysis in training appears on a recurring basis (Richter \& Paretti, 2009, Ashford, 2004). In the French context, the discipline is rather seen as an obstacle to the implementation of ESD and interdisciplinarity as difficult to implement. More than just on interdisciplinarity, studies examine possible convergences between specific disciplines (Vergnolle-Mainar, 2006) for the implementation of ESD.

The concern of fostering openness to divergent points of view and a capacity for dialogue, starting from different perspectives and points of view, is easier in an Anglo-Saxon context than in France, even if it acts mostly as an intention to practice and even if this refers also to debates. These aspects are found, for example when it comes to training engineers for sustainable development (Emilsson and Lilje, 2008, Lehman, Christensen et al. 2008).

The issue of skills development comes up regularly, which creates a problem in the choice of skills to develop, ways to teach and evaluate, and with very different answers according to the contexts.

It should be noted that the training for the ethical analysis of issues raised by sustainable development or ethical decision-making is more of an Anglo-Saxon specificity. It is seen as another challenge to the implementation of ESD in the context of university education (El-Zein, Airey et al. 2008), while the ethical considerations, even if they exist, are more marginal in France.

\section{Conclusion}

To characterize the specificity of ESD in the French university context of professional license programs, our case study highlights a centering on a non-prescribed curriculum that is centered mainly on good actions and eco-efficiency, and the contents are not derived from scientific knowledge. With the integration of sustainable development in programs, there is a decrease in disciplinary knowledge to focus on the acquisition of principles of governance related to sustainable development and project management. This change can be experienced in the French cultural space as a utilitarian education imposed by international institutions. No mention is made in these training programs regarding the integration of ethical concerns on sustainable development issues, nor on the question of engagement in the sense of critical education. We do not find any reflection on interdisciplinary training as a way to represent oneself and to analyze sustainable development considerations or as a work method that would allow the crossing of divergent interests and points of view in analysis and decision making. In this way, the integration of ESD in the French university context seems to stand out from the principles emphasized in Anglo-Saxon cultural contexts.

\section{Bibliography}


ALPE Y. (2006). "Quelle est la légitimité des savoirs scolaires", [What legitimacy in school knowledges], in Legardez A. \& Simonneaux L. [coord.], L'école à l'épreuve de l'actualité. Enseigner les questions vives [Teaching socially accute questions] Paris : ESF, p. 233-246.

ALPE Y. \& LEGARDEZ A. (2000). "Questions socialement vives, enjeux sociaux et didactiques : la création d'un enseignement d'éducation civique juridique et sociale en France", [Socially accute questions, social and didactical stakes] 13ème congrès international de la recherche en éducation au service du développement des sociétés, Association mondiale des sciences de l'éducation, Université de Sherbrooke, Canada.

AUDIGIER F. et TUTIAUX-GUILLON N. (2008). "Compétences et contenus. Les curriculums en questions" [Competence and content, questionning curriculums], in Bruxelles, Perspectives en éducation et formation, [perspectives in education] Bruxelles, De Boeck. 210 p.

ADOMßENT M., GODEMANN J., MICHELSEN G., (2007), "Transferability of approaches to sustainable developement at universities as a challenge". International Journal of Sustainability in Higher Education, Vol. _ No. ', 2007 pp. 385-402

ASHFORD N. A. (2004). "Major Challenges to Engineering Education for Sustainable Development: What Has to Change to Make It Creative, Effective, and Acceptable to the Established Disciplines?" International Journal of Sustainability in Higher Education 5(3): 239250.

BADER B. (2008). Education. Dans J. Golson, P. Geoffrey \& S. George (Eds.), Encyclopedia of global warming and climate change (p. 354-357). Thousand Oaks, CA: Sage Publications. Collection Sage reference.

BADER B. (2005). "Rapprochement interdisciplinaire entre une éducation aux sciences citoyenne et l'éducation relative à l'environnement : points de vue de chercheurs et formation des enseignants ». [Interdisciplinarity, citizen science education and environmental education: perspectives of researchers and teacher training.] Actes du colloque Le croisement des savoirs au coeur des recherches en éducation relative à l'environnement, UQAM : Acfas, mai 2004.

BARTHES A., CHAMPOLLION P., (2011), "Éducation au développement durable et territoires ruraux. Problématique, projet de territoire et réduction fonctionnelle de l'enseignement " [Education for sustainable developement and territories; rural cases], Éducation relative à l'environnement, Regards. Recherches. Réflexions, $\mathrm{n}^{\circ} 10$, Québec

BAUDELOT C. \& ESTABLET R. (1972). L'école capitaliste en France. [Capitalist school in France] Paris : Maspéro.

BERINGER A., \& ADOMSSENT M. (2008). "Sustainable university research and development: inspecting sustainability in higher education research", Environmental Education Research, Volume 14, Issue 6

BERINGER A., ADOMßENT M. \& SCOTT W. (2008): Editorial, Environmental Education Research, 14:6, 603-606

BERTHELOT J.-M., MARTIN O., COLLINET C. (2005). Savoirs et savants, Les études sur la science en France. [Knowledges and scientiste, science in France studies], Paris : PUF

BOURDIEU P. \& PASSERON J.C. (1970). La Reproduction. Éléments pour une théorie du système d'enseignement. [Reproduction. Elements for a theory of the education system] Paris : Éditions de Minuit

BRUXELLE Y. (2006). "Le partenariat, entre réticences et fascination : quels questionnements éthiques pour l'institution scolaire? [The partnership between reluctance and fascination: what ethical questions for the school] "Éducation Relative à L'environnement Regards. Recherches. Réflexions., vol 6, p.159- 178.

CORCORAN P.B., OSANO P.M., (2009), Young people, education and sustainable development: 
exploring principles, perspectives and praxis, Wageningen Academic Piblishers

DEVELAY M. (1998). Éduquer et Former. [Educating and teaching] Paris: Ed. Sciences Humaines.

DUBOIS M. (2001). La nouvelle sociologie des sciences. [New sociology of sciences] Paris: PUF.

DURKHEIM E. (1992). Éducation et sociologie. [Education and sociology] Paris, PUF (1ère éd. 1922)

EMILSSON U. M. \& LILJE B. (2008). "Training Social Competence in Engineering Education: Necessary, Possible or Not Even Desirable? An Explorative Study from a Surveying Education Program " European Journal of Engineering Education 33(3): 259-269.

EYMARD C. (2004). "Essai de modélisation des liens entre éducation et santé", [modelling essay between Health and Education »Questions vives, éduquer à ou pour la santé, quels enjeux pour la formation et pour la recherche ?, Volume 3 - Numéro 5

EL-ZEIN, A., AIREY D., et al. (2008). "Sustainability and Ethics as Decision-Making Paradigms in Engineering Curricula." International Journal of Sustainability in Higher Education 9(2): 170182. 3.1, 4.5

FERRER-BALAS D., ADACHI J., BANAS S., DAVIDSON C.I., HOSHIKOSHI A., MISHRA A., MOTODOA Y., ONGA M. \& OSTWALD M. (2008). "An international comparative analysis of sustainability transformation across seven universities", International Journal of Sustainability in Higher Education, Vol. 9 No. 3, 2008 pp. 295-316

GAYFORD C. (2002). Controversial environmental issues: a case study for the professional development of science teachers. International Journal of Science Education, 24, 1191-1200.

GIRAULT Y. \& SAUVE L. (2008). "L'éducation scientifique, l'éducation à l'environnement et l'éducation au développement durable, croisements, enjeux et mouvances" ASTER n 46, p. 1-21. GIROUX H.A. (2006). America on the Edge: Henry Giroux on Politics, Culture and Education. Basingstoke : Palgrave MacMillan.

GLASMAN D. (2001). L'accompagnement scolaire. Sociologie d'une marge de l'école, [schools and students accompaniment ], Paris : PUF

GOVERNMENT OF QUEBEC (2008). Science and technology. Secondary cycle two. Québec:

Ministère de l'Éducation du Loisir et du Sport. Retrieved from http://www.mels.gouv.qc.ca/sections/programmeformation

JOSHUA S. (1999). L'école entre crise et refondation. [Crisis and evolution in schools] Paris : La Dispute

JICKLING B. \& WALS J. A. (2008). "Globalization and environmental education: looking beyond sustainable development", Curriculum studies, Vol. 40, NO. 1, 1-21

JICKING B. (1992). "Why I don't want my children to be educated for sustainable development". The journal of environmental education, 23(4), 5-8.

LANGE J-M. (2008), ESD, supports and barriers, 2008 - 2012, ANR report

Logique de l'action collective.

LAVAL C. \& WEBER L. (2002). Le nouvel ordre éducatif mondial. [The new world education structure] Paris: Éditions Nouveaux Regards et Éditions Syllepse.

LEGARDEZ A. (2006). "Enseigner les questions socialement vives, quelques points de repères ? vives" [Teaching socially accute questions], in Legardez A. et Simmoneaux L. [coord.], L'école à l'épreuve de l'actualité, enseigner les questions socialement vives. Paris : ESF., p.19-32.

LEHMANN M., CHRISTENSEN P. (2008). "Problem-Oriented and Project-Based Learning (POPBL) as an Innovative Learning Strategy for Sustainable Development in Engineering Education." European Journal of Engineering Education 33(3): 283-295. 
MERLE P. (2009). La démocratisation de l'enseignement. Paris : [democratisation in schools], La Découverte.

MICHEL A. (2001). "Six scénarios sur l'école", [Six scenarios about school] Futuribles, n² 266, juillet-août 2001

MONJO R. (1998). "La forme scolaire dans l'épistémologie des sciences de l'éducation", [School structure and epistemology] Revue Française de Pédagogie, no125, pp. 83-93.

OLSON M. (1978). Paris : PUF.

OULTON C., DILLON J., GRACE M. (2004). "Reconceptualizing the teaching of controversial issues" International Journal of Science Education, Volume 26, Issue 4, Pages 411 - 423

PERRENOUD P. (1993). "Curriculum: le formel, le réel, le cache" [Real and hidden curriculum]., in Houssaye, J. [dir.]. La pédagogie : une encyclopédie pour aujourd'hui. Paris : ESF, p. 61-76.

POULIOT C., BADER B., \& THERRIAULT G. (2010). "The notion of the relationship to knowledge: A theoretical tool for research in science education". International Journal of Environmental and Science Education, 5(3), 239-264.

PROST A. (1992). Éducation, société et politiques. Une histoire de l'enseignement en France de 1945 à nos jours. [education, society and politic: theaching history in France from 1945], Paris : Seuil.

RICHTER D. M. and PARETTI M. C. (2009). "Identifying Barriers to and Outcomes of Interdisciplinarity in the Engineering Classroom." European Journal of Engineering Education 34(1): 29-45.

ROPE F. \& TANGUY L. [dir.] (1994). Savoirs et compétences. De l'usage de ces notions dans l'école et l'entreprise. [Knowledges and competences: the use of it in school and in business] Paris : L'Harmattan

SAUVE L., BERRYMAN T. \& BRUNELLE R. (2003). "Environnement et développement : la culture de la filière ONU".[Environment and development :UN cultural elements ] In Sauvé, L. et Brunelle, R. [dir.] Environnements, Cultures et Développements. Éducation relative à l'environnement - Regards, Recherches, Réflexions, 4, p. 33-55

SAUVE L. (2001). "Le partenariat en éducation relative à l'environnement : pertinence et défis", [partnership in environmental education], Éducation relative à l'environnement Regard. Recherches. Réflexions, vol 3, p.21-35

SAUVE L. (2006). "L'organisation et la structuration du secteur de l'éducation en réponse au programme onusien du développement durable". [UN program in education for sustainable development and organization of education system] Former et éduquer pour changer nos modes de vie, Liaison Énergie-Francophonie, 72, Décembre 2006, p. 33-41.

SAUVE, L. (2007). L'équivoque du développement durable. [Ambiguous sustainable development] Chemin de Traverse, No 4, p. 31-47.

SEGALAS, J; FERRER-BALAS D., SVANSTROM M., LUNDQVIST U. MULDER K.F. (2009), (2009) "What has to be learnt for sustainability? A comparison of bachelor engineering education competences at three European universities, Sustainable sciences 4: 17-27

SIMONNEAUX J. \& SIMONNEAUX L. (2009). "Student socio-scientic reasoning on controversies from the viewpoint of education for sustainable developement": European Journal of Engineering Education 34(1)657-687

STEINER G. \& POSCH A. (2006). "Higher education for sustainability by means of transdisciplinary case studies: an innovative approach for solving complex, real-world problems." Journal of Cleaner Production 14(9-11): 877-890. 
STERLING S. \& SCOTT W. (2008). "Higher education and ESD in England: a critical commentary on recent initiative", Environmental Education Research, Volume 14, Issue 4

VERGNOLLE-MAINAR C. (2006). "Quelle convergence entre la géographie et l'histoire dans une perspective d'éducation au développement durable" [Convergences between history and geography in perspectives of educating for sustainable development]. Éducation relative à l'environnement, Regards. Recherches. Réflexions, $\mathrm{n}^{\circ} 6$, Québec

VILLEMAGNE C. (2006). L'éducation relative à l'environnement des adultes en contexte communautaire: vers un modèle théorique [Environmental Community Adult Education: An Emerging Theoretical Model]. Rhizome, Newsletter of the Environmental Studies Association of Canada, 15 (2), 12-15.

VINCENT G. (dir.) (1994). L'éducation prisonnière de la forme scolaire. [Education captive fromschool structure ] Lyon : Presses universitaires de Lyon.

VINCK D. (1997) Sociologie des sciences. [Siences sociology]. Paris: A. Colin 